\title{
Chlorine solubility in evolved alkaline magmas
}

\author{
Michael R. Carroll \\ Dipartimento di Scienze della Terra, Università degli Studi di Camerino, Italy
}

\begin{abstract}
Experimental studies of $\mathrm{Cl}$ solubility in trachytic to phonolitic melts provide insights into the capacity of alkaline magmas to transport $\mathrm{Cl}$ from depth to the earth's surface and atmosphere, and information on $\mathrm{Cl}$ solubility variations with pressure, temperature and melt or fluid composition is crucial for understanding the reasons for variations in $\mathrm{Cl}$ emissions at active volcanoes. This paper provides a brief review of $\mathrm{Cl}$ solubility experiments conducted on a range of trachytic to phonolitic melt compositions. Depending on the experimental conditions the melts studied were in equilibrium with either a Cl-bearing aqueous fluid or a subcritical assemblage of low$\mathrm{Cl}$ aqueous fluid $+\mathrm{Cl}$-rich brine. The nature of the fluid phase(s) was identified by examination of fluid inclusions present in run product glasses and the fluid bulk composition was calculated by mass balance. Chlorine concentrations in the glass increase with increasing $\mathrm{Cl}$ molality in the fluid phase until a plateau in $\mathrm{Cl}$ concentration is reached when melt coexists with aqueous fluid + brine. With fluids of similar $\mathrm{Cl}$ molality, higher $\mathrm{Cl}$ concentrations are observed in peralkaline phonolitic melts compared with peraluminous phonolitic melts; overall the $\mathrm{Cl}$ concentrations observed in phonolitic and trachytic melts are approximately twice those found in calcalkaline rhyolitic melts under similar conditions. The observed negative pressure dependence of $\mathrm{Cl}$ solubility implies that $\mathrm{Cl}$ contents of melts may actually increase during magma decompression if the magma coexists with aqueous fluid and $\mathrm{Cl}$-rich brine (assuming melt-vapor equilibrium is maintained). The high $\mathrm{Cl}$ contents (approaching $1 \mathrm{wt} \% \mathrm{Cl}$ ) observed in some melts/glasses from the Vesuvius and Campi Flegrei areas suggest saturation with a $\mathrm{Cl}$-rich brine prior to eruption.
\end{abstract}

Key words alkaline magmas - solubility - chlorine supercritical fluid

\section{Introduction}

Chlorine generally occurs as a minor component in most magmas and fumarolic gases. However, it has been observed that the release of $\mathrm{Cl}$ from volcanoes to the atmosphere during eruptions and quiescent degassing may contribute to thinning of the ozone layer and the production of acid rain (Johnston, 1980; Devine

Mailing address: Dr. Michael R. Carroll, Dipartimento di Scienze della Terra, Università degli Studi di Camerino, Via Gentile III da Varano, 62302 Camerino, Italy; e-mail: michael.carroll@unicam.it et al., 1984; Symonds et al., 1988; Albritton, 1989). In addition, recent developments of spectroscopic methods to measure $\mathrm{Cl}$ and $\mathrm{S}$ emissions at active volcanoes offer the possibility to use measured variations in $\mathrm{Cl}$ and $\mathrm{S}$ emissions to better understand the subsurface movements of magmas and eruption likelihood (e.g., Francis et al., 1998; Love et al., 1998; Duffell et al., 2003; Edmonds et al., 2003). However, such applications require adequate knowledge of the factors controlling $\mathrm{Cl}$ distribution between melt and fluid(s) in decompressing magmas.

In recent years the study of volatiles in melt (now glass) inclusions has provided a wealth of data about $\mathrm{Cl}$ abundance in silicate melts under magmatic conditions (e.g., Lowenstern, 1995, and references therein). These data provide information on the amount of $\mathrm{Cl}$ dissolved in the melt at the time of melt inclusion entrapment. 


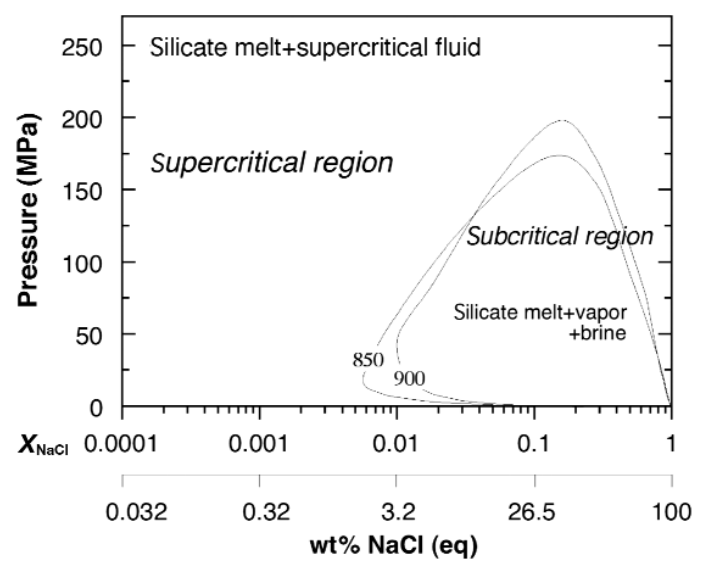

Fig. 1. Pressure- $X_{\mathrm{NaCl}}$ diagram of the system $\mathrm{NaCl}$ $-\mathrm{H}_{2} \mathrm{O}$ with 850 and $900^{\circ} \mathrm{C}$ isotherm (redrawn after Anderko and Pitzer, 1993a). The polythermal projection of the 3-phase vapor+brine +halite equilibrium onto the pressure-composition section is from Bishoff (1991) and Anderko and Pizer (1993a). Experiments with bulk $\mathrm{Cl}$ contents that fall within the solvus will coexist with both an aqueous fluid phase (containing a small amount of $\mathrm{Cl}$ ) and a salt-rich brine.

Although the absolute amount of $\mathrm{Cl}$ in magmas is difficult to estimate, the knowledge of solubility limits is of fundamental importance for interpretation of glass inclusion $\mathrm{Cl}$ abundance. In many cases, solubility data provide an upper limit on the volatile content of melts and they also provide indirect information about the presence of Cl-bearing fluid(s) within the magma body.

This paper reviews some recent work involving experimental determination of the solubility and the fluid/melt partitioning of chlorine in hydrous, evolved alkaline magmas at shallow crustal depths $(<\sim 8 \mathrm{~km})$. $\mathrm{Cl}$ solubility behavior at crustal pressures differs somewhat from that of water and carbon dioxide because in Cl-rich systems the silicate melts may also coexist with a Cl-rich brine. Most experimental studies of $\mathrm{Cl}$ solubility in hydrous systems have added $\mathrm{Cl}$ to the experimental samples using aqueous $(\mathrm{Na}, \mathrm{K})$ Cl solutions (Shinohara et al., 1989; Métrich and Rutherford 1992; Webster, 1992a,b; Student and Bodnar 1999; Signorelli and Carroll, 2000, 2001, 2002). This approach allows description of the behavior of Cl-bearing fluid using the well-known system NaCl- $\mathrm{H}_{2} \mathrm{O}$ (Sourirajan and Kennedy 1962; Bodnar et al., 1985; Chou, 1987; Anderko and Pitzer 1993a,b). For $\mathrm{H}_{2} \mathrm{O}-$ rich solutions, the binary phase relations (fig. 1) show a single fluid phase of variable composition at high pressures or low $\mathrm{Cl}$ concentrations. Published experimental data for silicate melts coexisting with low-Cl fluids, or with supercritical Cl-bearing fluids show that $\mathrm{Cl}$ partitions strongly into aqueous fluids relative to silicate melts by a factor of $\sim 20$ to 300 (e.g., Holland, 1972; Kilinc and Burnham, 1972; Webster, 1992a,b; Kravchuk and Keppler, 1994; Student and Bodnar, 1999). Webster (1992a,b) has also found that $\mathrm{Cl}$ concentration in rhyolitic melts coexisting with a single aqueous fluid phase with low $\mathrm{Cl}$ content $(<20 \mathrm{wt} \% \mathrm{Cl}$ ) decreases as pressure increases from 200 to $800 \mathrm{MPa}$ and the fluid/melt partition coefficient for $\mathrm{Cl}$ increases with increasing pressure.

However, with increasing concentration of $\mathrm{Cl}$ in the solution at pressures below $\sim 200 \mathrm{MPa}$, the binary system $\mathrm{H}_{2} \mathrm{O}-\mathrm{NaCl}$ is characterized by an immiscibility gap (subcritical region; see fig. 1) within which a Cl-poor, aqueous fluid coexists with a Cl-rich, hydrosaline brine. Within the subcritical region, the compositions of aqueous fluid and brine are invariant at constant pressure and temperature, which means that $\mathrm{Cl}$ and $\mathrm{H}_{2} \mathrm{O}$ concentrations in the fluids and the coexisting silicate melt will be fixed (Gibbs' phase rule). A constant $\mathrm{Cl}$ content in the glass (flat distribution or plateau) for further addition of $\mathrm{Cl}$ to the system is the typical expression of the melt being saturated with both a hydrosaline liquid and an $\mathrm{H}_{2} \mathrm{O}$-rich aqueous fluid and it is assumed to define the solubility limit for $\mathrm{Cl}$ in the hydrous silicate melt (Malinin et al., 1989; Shinohara et al., 1989; Métrich and Rutherford, 1992; Webster, 1992a,b; Signorelli and Carroll, 2000, 2001, 2002). Experiments carried out in this region (coexisting silicate melt + aqueous fluid + brine) for hydrous rhyolitic melts have documented that: 1) chlorine does not partition strongly into the water-rich fluid phase and the aqueous flu$\mathrm{id} /$ melt partition coefficient is $\sim 5$ at $100 \mathrm{MPa}$ (Webster and Holloway, 1988; Shinohara et al., 1989; Métrich and Rutherford, 1992; Candela and Piccoli, 1995; Williams, 1995); 2) there is a 
positive correlation between the fluid/melt distribution coefficient and total pressure (Shinohara et al., 1989; Malinin et al., 1989); and 3) chlorine solubility, that is the maximum amount of $\mathrm{Cl}$ in a melt coexisting with a brine + aqueous fluid assemblage, depends strongly on melt composition (e.g., Webster and De Vivo, 2002) and pressure. The solubility varies from a few thousand ppm to $\sim 1 \mathrm{wt} \%$, being higher in peralkaline rhyolites (pantellerites) relative to metaluminous compositions (Shinohara et al., 1989; Métrich and Rutherford, 1992) Results presented in this review paper extend these observations to consider trachytic and phonolitic melts, which have much higher $\mathrm{Cl}$ solubilities than typical calcalkaline rhyolitic melt compositions.

Silicate melts can be saturated with respect to a fluid phase (e.g., $\mathrm{H}_{2} \mathrm{O}, \mathrm{CO}_{2}$, noble gases) or a mineral phase (e.g., anhydrite or pyrrhotite for S-bearing magmas). The solubility of $\mathrm{Cl}$ is a more complex and ambiguous term since the silicate melt can be saturated with respect to mineral, liquid and fluid phases (e.g. halite, pure liquid $\mathrm{NaCl}$ or a Cl-rich brine, $\mathrm{Cl}_{2}, \mathrm{HCl}$ or $\mathrm{Cl}$-bearing aqueous fluids). Throughout this paper, the term solubility is used to refer to the maximum amount of $\mathrm{Cl}$ that can be dissolved in the silicate melt when it is saturated with an immiscible aqueous fluid + brine assemblage at a given set of conditions. The distribution of $\mathrm{Cl}$ between a melt and an aqueous phase is generally expressed in the literature as Nernst-type partition coefficients $\left(D_{\mathrm{m} / \mathrm{aq}, \mathrm{Cl}}\right.$, where $\mathrm{m}=$ melt, $\mathrm{aq}=$ aqueous fluid). However, only components that can vary independently in a phase or a system have a real distribution coefficient (Candela and Piccoli, 1995) and this is not strictly true for $\mathrm{Cl}$ (although it would be true for components such as $\mathrm{NaCl}, \mathrm{KCl}$, etc.; e.g., see Candela and Piccoli, 1995; Frank et al., 2003). However, given the lack of knowledge concerning $\mathrm{Cl}$ speciation in the fluid phase, a simple Nernst-style partition coefficient is often used in discussion of melt-fluid partitioning of $\mathrm{Cl}$.

\section{Pressure and Cl solubility}

The solubility of $\mathrm{Cl}$ in phonolitic melts equilibrated with $\mathrm{Cl}$-bearing fluids over a range
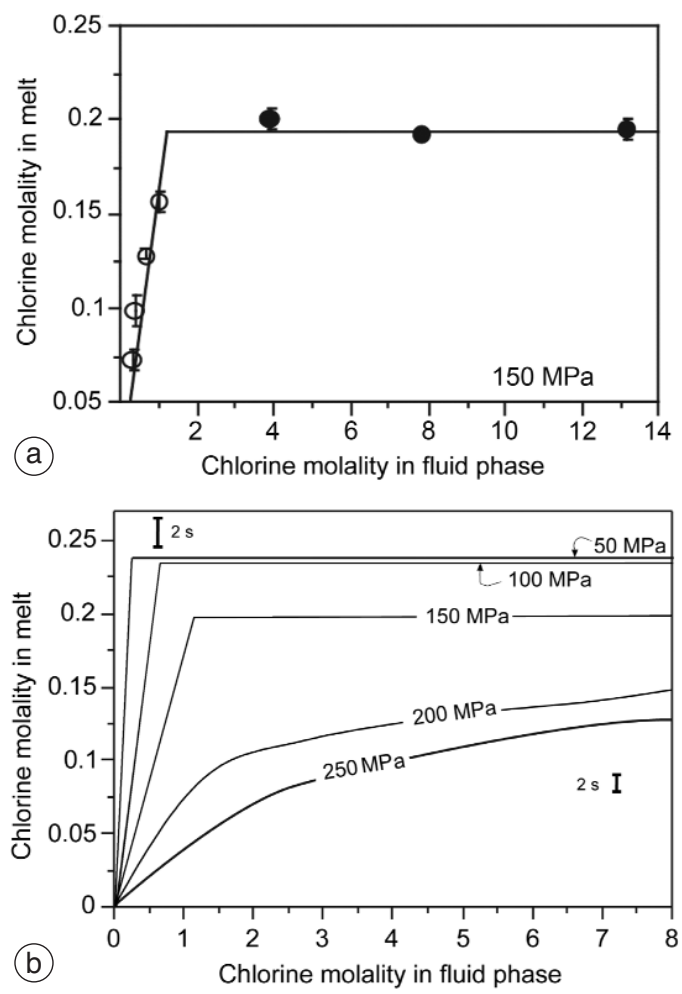

Fig. 2a,b. Variation of the chlorine molality in the melt with the calculated chlorine molality in a single fluid phase (for brine-saturated conditions this is an «apparent molality» because the melt coexists with both $\mathrm{Cl}$-poor aqueous fluid and $\mathrm{Cl}$-rich brine). a) Chlorine molality $\left(\mathrm{C}_{\mathrm{m}, \mathrm{Cl}}\right)$ of $\mathrm{MB}$ phonolitic melts versus $\mathrm{Cl}$ molality at $P=150 \mathrm{Mpa}, T=850^{\circ} \mathrm{C}$. Experiments carried out in the two-phase field (melt + aqueous fluid) are represented as open circles and those in the three-phase field (melt + aqueous fluid +hydrosaline brine) are represented as solid circles. b) Summary of variation of the chlorine molality in the melt with the chlorine molality in a single fluid phase (experimental data points not shown). The vertical bars show the two-sigma standard deviations on analyses of chlorine in the silicate melt $\mathrm{C}_{\mathrm{m}, \mathrm{Cl}}(\mathrm{moles} / \mathrm{kg}) \mathrm{C}_{\mathrm{m}, \mathrm{Cl}}$ $(\mathrm{ppm}) / 35450$ (data from Signorelli and Carroll, 2000).

of pressures and fluid $\mathrm{Cl}$ contents, as determined by Signorelli and Carroll (2000), is shown in fig. $2 \mathrm{a}, \mathrm{b}$. The melt composition used in these experiments is given in table I and experimental details are given in Signorelli and 
Table I. Composition (wt\%) on water free basis of experimental starting materials.

\begin{tabular}{ccccccccc}
\hline \hline Sample & $\begin{array}{c}\text { Montaña } \\
\text { Blanca } \\
\text { MB }\end{array}$ & $\begin{array}{c}\text { Vesuvius } \\
\text { Ves }\end{array}$ & $\begin{array}{c}\text { Phlegraean } \\
\text { Fields } \\
\text { CI }\end{array}$ & $\begin{array}{c}\text { Vesuvius } \\
\text { VS }\end{array}$ & $\begin{array}{c}\text { Vulsini } \\
\text { O }\end{array}$ & $\begin{array}{c}\text { Zikwala } \\
\text { ER }\end{array}$ & $\begin{array}{c}\text { Seite } \\
\text { Cidades } \\
\text { SM }\end{array}$ & $\begin{array}{c}\text { Synthetic } \\
\text { phonolite } \\
\text { D }\end{array}$ \\
\hline $\mathrm{SiO}_{2}$ & 59.5 & 57.3 & 62.1 & 62.9 & 59.9 & 68.3 & 64.6 & 58.7 \\
$\mathrm{TiO}_{2}$ & 0.66 & 0.19 & 0.44 & 0.37 & 0.55 & 0.53 & 0.63 & \\
$\mathrm{Al}_{2} \mathrm{O}_{3}$ & 19.0 & 21.7 & 18.60 & 18.00 & 17.9 & 13.8 & 16.9 & 24.5 \\
$\mathrm{FeO}$ & 3.34 & 2.23 & 3.30 & 3.07 & 4.00 & 5.81 & 3.00 & \\
$\mathrm{MnO}$ & 0.2 & 0.13 & 0.24 & 0.16 & 0.12 & 0.28 & 0.20 & \\
$\mathrm{MgO}$ & 0.33 & 0.23 & 0.35 & 0.46 & 1.06 & 0.16 & 0.35 & \\
$\mathrm{CaO}$ & 0.79 & 2.94 & 1.77 & 2.68 & 4.34 & 0.75 & 0.63 & \\
$\mathrm{Na} 2$ & 10.09 & 5.68 & 5.64 & 4.09 & 2.87 & 5.90 & 7.79 & 11.30 \\
$\mathrm{~K}_{2} \mathrm{O}$ & 5.56 & 9.53 & 7.32 & 8.10 & 8.78 & 4.11 & 5.63 & 5.50 \\
$\mathrm{P}_{2} \mathrm{O}_{5}$ & 0.07 & 0.04 & 0.02 & 0.04 & 0.17 & 0.06 & 0.07 & \\
$\mathrm{Cl}$ & 0.35 & 0.55 & 0.59 & 0.55 & 0.16 & 0.08 & 0.21 & \\
$\mathrm{~F}$ & 0.09 & 0.4 & 0.34 & 0.19 & 0.37 & 0.10 & 0.17 & \\
$\mathrm{LOI}$ & 0.45 & 3.10 & 2.50 & 1.40 & 2.60 & 0.57 & 0.20 & \\
{$[2] \mathrm{AI}$} & 1.2 & 0.91 & 0.92 & 0.86 & 0.79 & 1.03 & 1.12 & 1.0 \\
{$[3] \mathrm{A} / \mathrm{CNK}$} & 0.8 & 0.87 & 0.91 & 0.88 & 0.81 & 0.89 & 0.84 & 1.0 \\
\hline
\end{tabular}

Major elements, $\mathrm{Cl}$ and $\mathrm{F}$ for $\mathrm{MB}$ have been determined by $\mathrm{XRF}$. $\mathrm{FeO} *$ total $\mathrm{Fe}$ as $\mathrm{FeO}$; for Ves analysis $\mathrm{Cl}$ and $\mathrm{F}$ determined by potenziometry; $\mathrm{LOI}=$ Loss On Ignition; [2] Agpaitic Index $=\left[\left(\mathrm{Na}_{2} \mathrm{O}+\mathrm{K}_{2} \mathrm{O}\right) / \mathrm{Al}_{2} \mathrm{O}_{3}\right]$ molar ratio; [3] molar $\left[\left(\mathrm{Al}_{2} \mathrm{O}_{3} / \mathrm{CaO}+\mathrm{Na}_{2} \mathrm{O}+\mathrm{K}_{2} \mathrm{O}\right)\right]$ ratio (see for details Signorelli and Carroll, 2000, 2002); alkali exchange and partial crystallization in some experiments resulted in slightly different experimental melt compositions, as documented in Signorelli and Carroll $(2000,2002)$.

Carroll (2000); all of the experiments involved equilibration of silicate melt with $(\mathrm{Na}, \mathrm{K}) \mathrm{Cl}$ solutions of variable initial chloride molality and fluid compositions at the end of the experiments was calculated by mass-balance. These experiments may contain two types of fluid inclusions trapped in the quenched glass: type-I inclusions contain both a vapor bubble and a liquid phase, whereas type-II fluid inclusions contain a vapor bubble, liquid and one or more daughter minerals (salts). The minerals contained in these inclusions are believed to be alkali chlorides, possibly with other chlorides (e.g., $\mathrm{CaCl}_{2}$ and $\mathrm{FeCl}_{2}$ ). Only experiments from below $200 \mathrm{MPa}$ are found to contain both typeI and type-II inclusions. Experiments above $200 \mathrm{MPa}$ contain only type-II inclusions. The experiments carried out between 50 and 150 MPa display the common behavior of a positive linear correlation between $\mathrm{Cl}$ in glass and in the fluid phase, when $\mathrm{Cl}$ molality in the fluid phase is below $\sim 2 m \mathrm{Cl}$, and then a flat distribution where further increases in the total amount of $\mathrm{Cl}$ in the system do not increase $\mathrm{Cl}$ in the glass (fig. 2a). The experiments at 200 and $250 \mathrm{Mpa}$ show a parabolic increase in melt $\mathrm{Cl}$ content with increasing $\mathrm{Cl}$ in the fluid (i.e., the rate of increase in melt $\mathrm{Cl}$ content slows in experiments with more Cl-rich fluids). Figure $2 \mathrm{~b}$ shows the isobaric trends for all of the data superimposed on the same diagram $(T=850$ $875^{\circ} \mathrm{C}$ ). This comparison clearly shows that as pressure increases there is a decrease in the slope of the straight line (melt coexists with single fluid of variable $\mathrm{Cl}$ content; positive slope) and a shift of the pivot point between the straight line and the plateau (melt coexists with both aqueous fluid and brine) towards more $\mathrm{Cl}$ rich fluids until the sharp break of slope between them turns into a smooth passage be- 


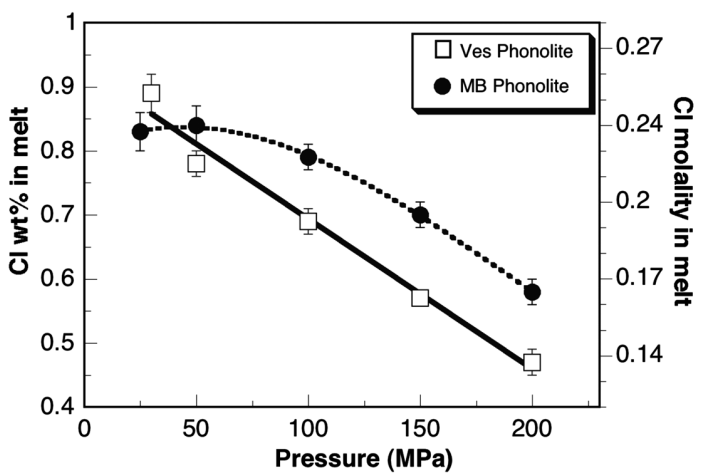

Fig. 3. Chlorine solubility in phonolitic melts saturated with aqueous fluid+brine versus pressure. Solid circles and open squares represent MB (Montaña Blanca, Teneriffe) and Vesuvius phonolitic glasses ( $\pm 1 \sigma$ standard deviation), respectively (data from Signorelli and Carroll, 2000). tween 200 and $250 \mathrm{MPa}$. These results indicate that the melt $\mathrm{Cl}$ content decreases as pressure increases when the melt is saturated with both an aqueous fluid phase and a brine phase, as shown in fig. 3 for 2 phonolitic compositions (Vesuvius 79 A.D. and Montaña Blanca, Teneriffe; supercritical values taken from solubility at 2 molal $\mathrm{Cl}$ in fluid). The lack of change in melt $\mathrm{Cl}$ contents for the $\mathrm{MB}$ phonolite at pressures below $100 \mathrm{Ma}$ is probably due to the fact that this composition begins to crystallize at the lowest pressures investigated and the changes in melt composition result in decreased $\mathrm{Cl}$ solubilities, as predicted by the model of Webster and De Vivo (2002) and discussed further below. The $\mathrm{Cl}$ contents of the brine and aqueous fluid phases coexisting with these melts at any pressure (below the top of the miscibility gap) can be estimated from the $\mathrm{H}_{2} \mathrm{O}-\mathrm{NaCl}$ binary
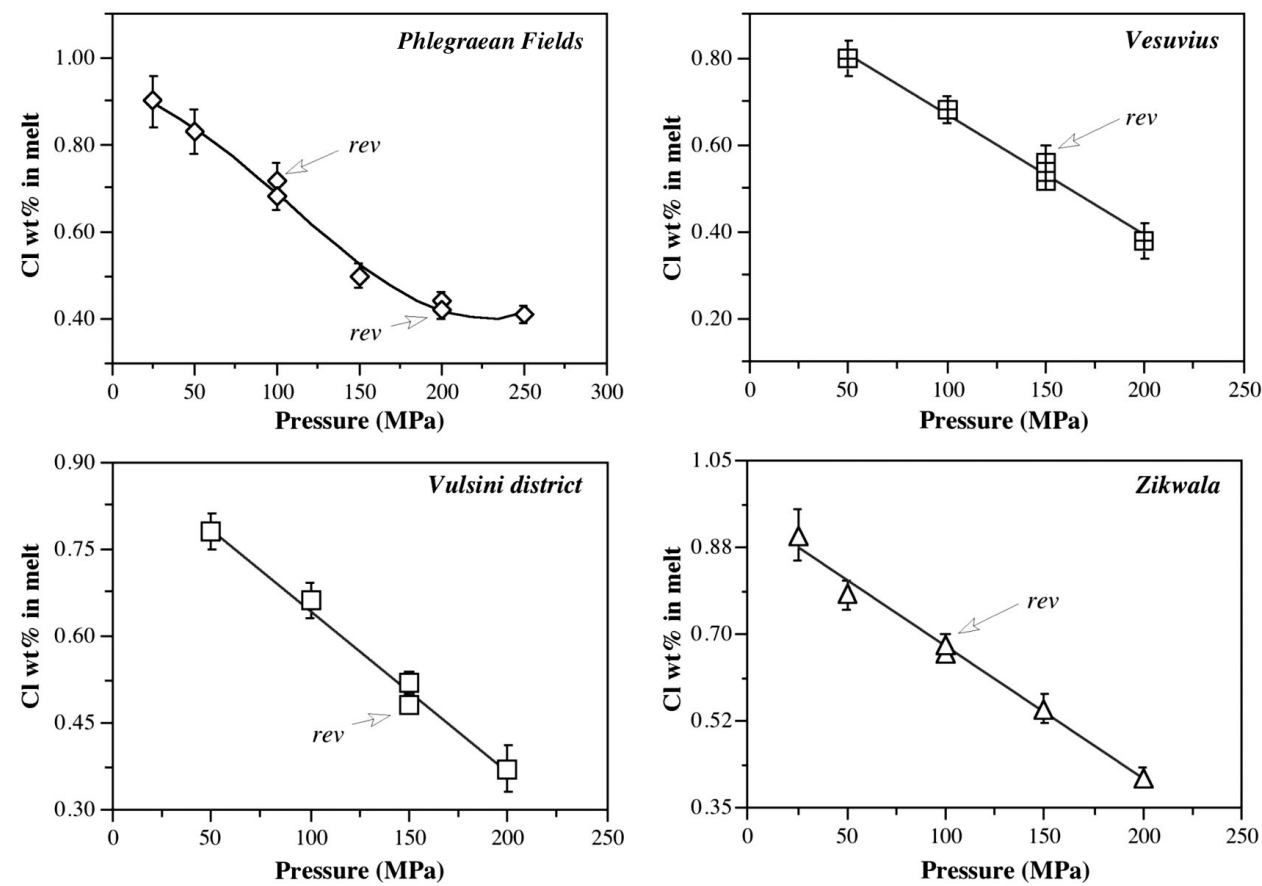

Fig. 4. Chlorine solubility $( \pm 1 \sigma$ standard deviation) in trachytic (Signorelli and Carroll, 2002) and phonolitic melts (Signorelli and Carroll, 2000) saturated with aqueous fluid+brine versus pressure. «This study» refers to Signorelli and Carroll (2002). Original melt compositions are given in table I and «rev» refers to reversal experiments. 
shown in fig. 1. As indicated in fig. 1, the brine phase actually becomes more $\mathrm{Cl}$-rich as pressure decreases and this may explain why the melt also becomes more $\mathrm{Cl}$-rich as pressure decreases - if the $\mathrm{Cl}$ activity in the brine increases as pressure decreases, then the $\mathrm{Cl}$ activity in the coexisting melt also increases as pressure decreases (see also thermodynamic-molar volumes discussion in Signorelli and Carroll, 2002). The effect of $\mathrm{KCl}$ (and other chlorides) on the field of immiscibility has not been considered due to lack of data but studies at lower temperature $\left(400-600^{\circ} \mathrm{C}\right)$ suggest that the addition of $\mathrm{KCl}$ tends to enlarge the field of immiscibility but does not change the general geometry of the binary (Anderko and Pitzer, 1993b).

$\mathrm{Cl}$ solubility in trachytic melts saturated with both an aqueous fluid phase and a brine phase shows variation with pressure very similar to that observed for phonolitic melts, as shown for a variety of trachytic melts in fig. 4 (data from Signorelli and Carroll, 2002). The compositions of the trachytic melts studied are reported in table I and the variations in $\mathrm{Cl}$ solubility with melt composition are discussed below.

\section{Melt composition and $\mathrm{Cl}$ solubility}

Experimental studies involving hydrous rhyolitic to phonolitic melts equilibrated with an aqueous vapor and a hydrosaline liquid have shown that the behavior of chlorine in the melt is a strong function of the melt composition and in general $\mathrm{Cl}$ solubilities are higher in more Si-poor melts (e.g., Métrich and Rutherford, 1992; Carroll and Webster, 1994 and references therein; Webster et al., 1999; Signorelli and Carroll, 2001, 2002; Webster and De Vivo, 2002). Métrich and Rutherford (1992) found that the peraluminous-peralkaline character of a silicate melt, expressed as molar ratio of $\mathrm{Na}_{2} \mathrm{O}+\mathrm{K}_{2} \mathrm{O} / \mathrm{Al}_{2} \mathrm{O}_{3}$ (= Agpaitic Index, $\mathrm{AI}$ ), has a large effect on $\mathrm{Cl}$ solubility in hydrous rhyolitic melts, as shown in fig. 5. A change of melt composition from metaluminous rhyolite to peralkaline pantellerite yields a more than 3fold increase in $\mathrm{Cl}$ solubility (fig. 5). On the other hand, Signorelli and Carroll (2001), working with a peraluminous rhyolitic compo- sition, found that $\mathrm{Cl}$ solubility is higher in peraluminous rhyolites than in metaluminous rhyolites and the increase of $\mathrm{Cl}$ solubility with peraluminosity is possibly even more pronounced than the changes observed with increasing peralkalinity (e.g., at $100 \mathrm{MPa}$, brine + + aqueous fluid saturation, peraluminous rhyolite with $\mathrm{AI}=0.8$ has $0.64 \mathrm{wt} \% \mathrm{Cl}$ ). These results suggest a minimum $(\sim 3000 \mathrm{ppm})$ in $\mathrm{Cl}$ solubility in metaluminous rhyolites and higher $\mathrm{Cl}$ solubilities in both peralkaline and peraluminous compositions. $\mathrm{Cl}$ solubility in hydrous phonolites also depends on peralkalinity of the melt (Signorelli and Carroll, 2000) and the results of Signorelli and Carroll (2002) for a close-to-metaluminous phonolite (fig. 6) suggest a possible minimum $(\sim 0.48 \mathrm{wt} \%)$ in $\mathrm{Cl}$ solubility in metaluminous phonolites. The higher $\mathrm{Cl}$ solubility in metaluminous phonolite with respect to metaluminous rhyolite is probably due to the lower silica activity of phonolitic melts, as suggested by various previous studies that document increasing $\mathrm{Cl}$ solubility with decreasing silica activity (Kotlova et al., 1960; Iwasaki and Katsura, 1967; Webster, 1997a,b; Webster and Rebbert, 1998; Webster et al., 1999; Webster and De Vivo, 2002); note that decreasing silica activity is also correlated with increasing activities of network-modifying cations, as discussed further below. In fig.

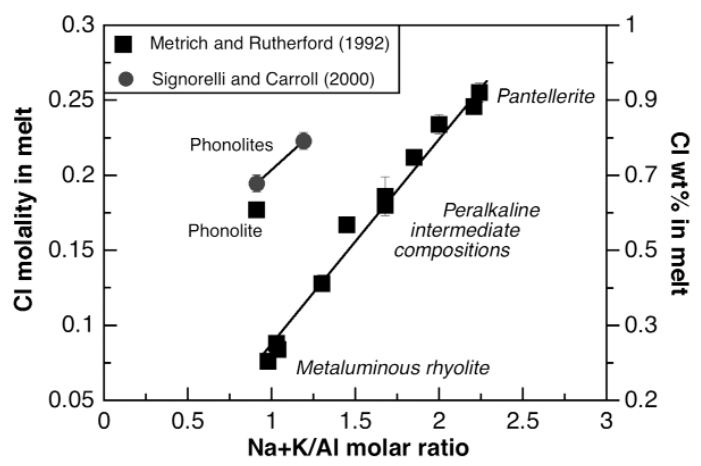

Fig. 5. Solubility of chlorine at $100 \mathrm{MPa}$ as a function of molar $(\mathrm{Na}+\mathrm{K}) / \mathrm{Al}$ ratio for natural rhyolites and phonolites saturated with an aqueous fluid + hydrosaline brine (data from Metrich and Rutherford, 1992; and Signorelli and Carroll, 2000). 


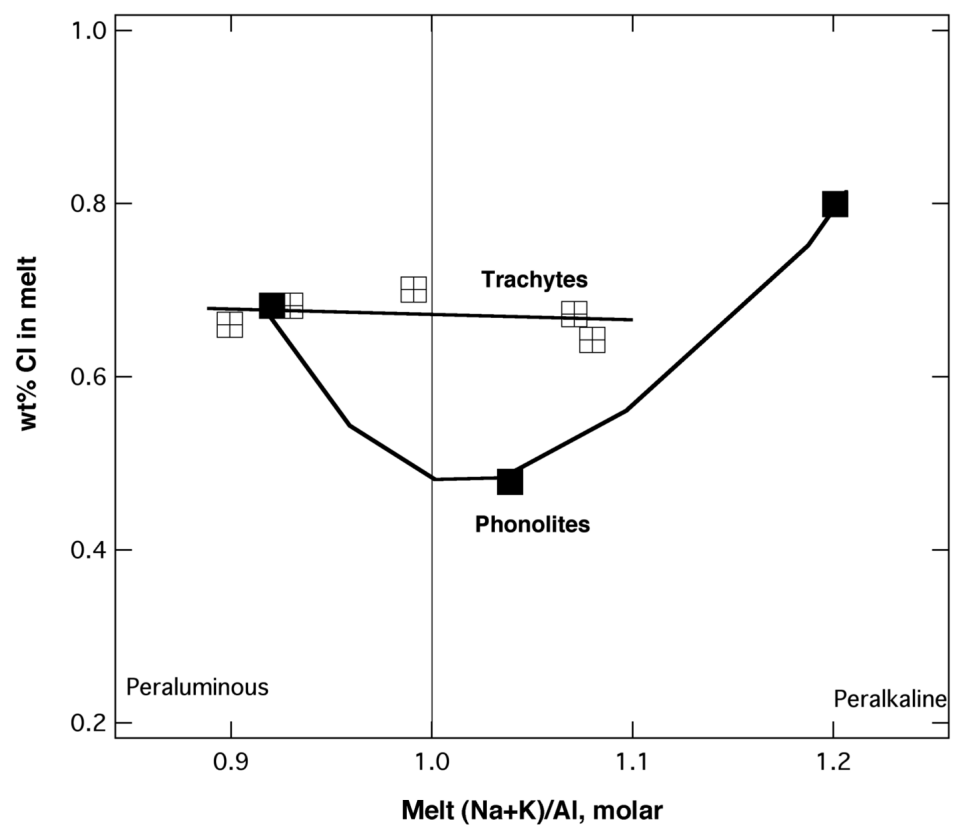

Fig. 6. Solubility of chlorine $\left( \pm 1\right.$ standard deviation) at $100 \mathrm{Mpa}, 850-875^{\circ} \mathrm{C}$ as a function of molar $[(\mathrm{Na}+\mathrm{K}) / \mathrm{Al}]$ ratio for natural trachytes (open symbols, from Signorelli and Carroll, 2002), and natural and synthetic phonolites (filled symbols, from Signorelli and Carroll, 2000) saturated with an aqueous fluid + hydrosaline liquid.

6 the results of Signorelli and Carroll (2002) for trachytic compositions with variable alkali/alumina are also shown. The most evident difference between the trachytic and phonolitic melts is that the trachytes don't show any minimum and $\mathrm{Cl}$ solubility is constant at approximately $0.67 \mathrm{wt} \%$ over the range of agpaitic index investigated (0.9-1.08). Apparently, the peraluminous-peralkaline character of the trachytic melt has little influence on $\mathrm{Cl}$ solubility, in contrast to the significant variations seen in phonolitic and rhyolitic compositions.

A possible explanation of the lack of variation in $\mathrm{Cl}$ solubility with peralkalinity comes from the recent study of Webster and De Vivo (2002) concerning the effects of melt composition on $\mathrm{Cl}$ solubility in a wide range of silicate melt compositions (41 different compositions, all at $\left.200 \mathrm{MPa}, 786-1193^{\circ} \mathrm{C}\right)$. Webster and De Vivo (2002) modelled the effects of melt composition on brine-saturated melts containing up to $3.2 \mathrm{wt} \% \mathrm{H}_{2} \mathrm{O}$ using the idea of association coefficients that express the effect of the molar abundance of each melt component (cations + $\mathrm{F}^{-}$) on $\mathrm{Cl}$ solubility (positive association coefficients indicate a component increases $\mathrm{Cl}$ solubility, negative values indicate components that reduce $\mathrm{Cl}$ solubility). They found that the affinity of individual cations for $\mathrm{Cl}$ decrease in the order $\mathrm{Mg} \sim \mathrm{Ca}>\mathrm{Fe}>\mathrm{Na}>\mathrm{K}>$ network-forming $\mathrm{Al}>\mathrm{Li} \sim \mathrm{Rb} \sim \mathrm{Cs} ; \mathrm{F}$ has a positive effect on $\mathrm{Cl}$ solubility. However, the relation between composition and solubility is more complex in peralkaline and peraluminous melts (because of possible variations in the structural role of $\mathrm{Al}$ ), and the effects of $\mathrm{Ca}, \mathrm{Mg}$ and $\mathrm{Al}$ are greater in mafic melts than in more silica-rich melts. Details of this model are explained in Webster and De Vivo (2002) and the good agreement between their model predictions and measured $\mathrm{Cl}$ solubilities at $200 \mathrm{MPa}$ for a wide range of melt compositions is shown in fig. 7. The fact that 


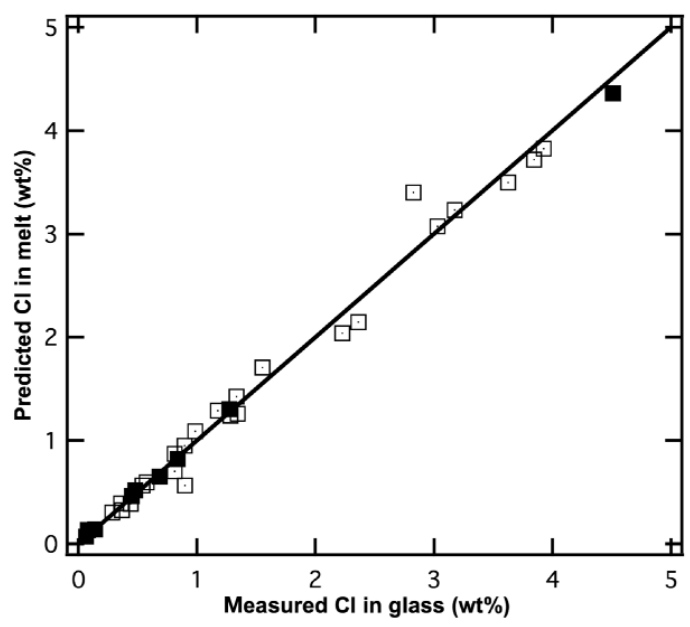

Fig. 7. Correlation between measured $\mathrm{Cl}$ solubilities and those predicted by the model of Webster and De Vivo (2002). All melts are saturated with a Clrich brine at $200 \mathrm{MPa}$ pressure and temperatures of $786-1193^{\circ} \mathrm{C}$. Filled symbols show experiments used to generate the model association coefficients and open symbols show melt compositions for which the $\mathrm{Cl}$ solubility was calculated using the model association coefficients. Typical $1-\sigma$ analytical precision for measured $\mathrm{Cl}$ contents are on the order of 0.05 to $0.1 \mathrm{wt} \%$.

$\mathrm{Mg}, \mathrm{Ca}$ and $\mathrm{Fe}$ have significantly greater effects on $\mathrm{Cl}$ solubilities than do $\mathrm{K}$ and $\mathrm{Na}$ may help explain why the $\mathrm{Cl}$ solubilities in trachytes studied by Signorelli and Carroll (2002) appear to be independent of alkali/alumina ratio. Following the results of Webster and De Vivo (2002), the higher abundances of $\mathrm{Mg}, \mathrm{Ca}$ and $\mathrm{Fe}$ in the trachytes overwhelm the effects of varying alkali/alumina, thus there is no significant variation in $\mathrm{Cl}$ solubility; such effects might be more apparent in more extremely peralkaline or peraluminous trachytes. Extrapolation of the results of Webster and De Vivo (2002) to other pressures, and consideration of the effects of melt $\mathrm{H}_{2} \mathrm{O}$ content on $\mathrm{Cl}$ solubility still need to be investigated. The use of association coefficients to quantify how melt composition variations affect $\mathrm{Cl}$ solubilities appears promising, but the approach is not completely general because numerous additional correc- tions are needed depending on the types of melts considered (e.g., peralkaline, peraluminous - see Appendix in Webster and De Vivo, 2002).

\section{Volcanological implications}

All studies of $\mathrm{Cl}$ solubility in hydrous rhyolites, phonolites and trachytes in the presence of subcritical $(\mathrm{Na}, \mathrm{K}) \mathrm{Cl}-\mathrm{H}_{2} \mathrm{O}$ fluids have shown that $\mathrm{Cl}$ solubility decreases regularly as the pressures rises. The higher $\mathrm{Cl}$ solubility in phonolites and trachytes with respect to rhyolites, however, suggests that evolved alkaline magmas can transport larger amounts of chlorine to the earth's surface. This reservoir of chlorine may be potentially emitted to the atmosphere if significant $\mathrm{Cl}$ is lost during cooling, crystallization and degassing of volcanic products.

The composition of high-temperature gases released from volcanoes depends on factors such as gas solubility in the silicate melt and vapor/melt partitioning and separation during the generation and rise of magmas. Giggenbach (1996) has proposed a model for equilibrium degassing (i.e., closed-system degassing) that takes into account these factors. However, this model requires that volatile solubilities approach Henry's Law behavior and that the solubilities decrease with decreasing pressure (as observed for $\mathrm{H}_{2} \mathrm{O}, \mathrm{CO}_{2}$, noble gases). The negative correlation of melt $\mathrm{Cl}$ concentration with pressure means that $\mathrm{Cl}$ solubility behavior in brine-saturated magmas cannot be treated as simply as other volatile species, at least when high melt $\mathrm{Cl}$ contents suggest brine saturation. The solubility of $\mathrm{Cl}$ may also be complicated by the formation of non-volatile alkali chlorides and $\mathrm{HCl}^{\circ}$ at low pressure. Alternatively, various authors have convincingly demonstrated that the potential distribution of $\mathrm{Cl}$ in magmatic fluids depends on the shape of the immiscibility solvus of $\mathrm{NaCl}-\mathrm{H}_{2} \mathrm{O}$ system (or a similar «salt»$-\mathrm{H}_{2} \mathrm{O}$ system) at low pressures and magmatic temperatures (e.g., Hedenquist and Lowenstern, 1994; Shinohara, 1994; Hedenquist, 1995). During decompression and/or crystallisation of a magma at low ( $<200 \mathrm{MPa}$ ) pressures it may be- 
come saturated with both a low-density vapor and a high-density brine (first and/or second boiling; see Webster and De Vivo, 2002). As described by Hedenquist and Lowenstern (1994), the low density phase will contain components such as $\mathrm{H}_{2} \mathrm{O}, \mathrm{CO}_{2}, \mathrm{SO}_{2}, \mathrm{H}_{2} \mathrm{~S}, \mathrm{HCl}$ and the higher density brine phase will contain alkali salts, metals, water and sulphates. The shape of solvus in the $\mathrm{NaCl}-\mathrm{H}_{2} \mathrm{O}$ binary (fig. 1) predicts that upon further isothermal decompression, the vapor and the brine will progressively become less and more saline, respectively.

Once information on $\mathrm{Cl}$ solubility in silicate melts is available, indirect evidence for immiscibility between silicate melts and $\mathrm{H}_{2} \mathrm{O}-\mathrm{NaCl}$ fluids is provided by the study of $\mathrm{Cl}$ concentrations in glass inclusions present in magmatic phenocrysts. These inclusions are small samples of silicate melt trapped during crystal growth and they represent the most accessible samples of non-degassed magma (e.g., Roedder, 1984; Lowenstern, 1995, and references therein; Signorelli et al., 2001; Webster and De Vivo, 2002). Alternatively, matrix glasses from rapidly erupted and cooled pumices (e.g., from Plinian eruptions) may provide useful information on some volatiles (e.g., Gardner et al., 1998; Signorelli and Capaccioni, 1999; Signorelli et al., 2001). For example, data collected from the literature on $\mathrm{Cl}$ contents of phonolitic glass inclusions and matrix glasses are presented in fig. 8. The content of $\mathrm{Cl}$ in these evolved alkaline melts is quite variable, ranging from 0.18 to $1.03 \mathrm{wt} \%$. The highest abundance of $\mathrm{Cl}$ occur in volcanic products from Vesuvius (1.03 wt $\%$ ), whereas the lowest pertain to Laacher See $(0.18 \mathrm{wt} \%)$, Montaña Blanca $(\sim 0.35 \mathrm{wt} \%)$ and Tambora $(\sim 0.2$ $w t \%)$. Provided that the magma was fluid saturated and the magmatic reservoir was located at pressures below about $200 \mathrm{MPa}$, the similarity of natural and experimental data for Vesuvius suggests that most Vesuvian phonolitic melts were saturated with respect to a hydrosaline liquid (brine). If these assumptions are also valid for Laacher See, Montaña Blanca and Tambora, the comparison between natural and experimental data suggests that these systems could not have been saturated with a hydrosaline brine prior to eruption. The comparison of $\mathrm{Cl}$ in glass inclusions and degassed matrix glasses, when

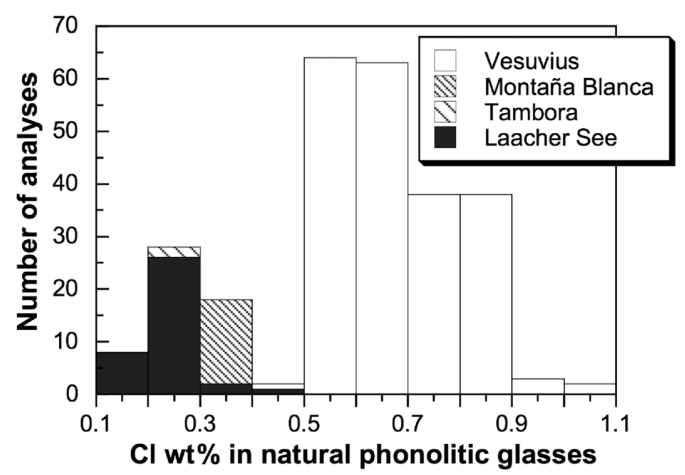

Fig. 8. Histogram of chlorine content of glass inclusions and matrix glasses from phonolites. The data are from the following volcanic systems: Vesuvius (Cornell and Sigurdsson, 1987; Mues-Schumacher, 1994 and unpubl.; Cioni et al., 1995, 1998; Signorelli and Capaccioni, 1999; Signorelli et al., 1999), Tambora (Devine et al., 1984), Montaña Blanca (Signorelli, unpubl.) and Laacher See (Harms and Schmincke, 2000).

possible, suggests that $\mathrm{Cl}$ may be retained in the silicate melts during the Plinian phase of phonolitic eruptions ( $\mathrm{Cl}$ degassing is slow on the eruption timescale). This is not the case of the Laacher See and Tambora eruption where chlorine has apparently shown a volatile behavior, with $\mathrm{Cl}$ content in matrix glasses lower than in glass inclusions (Devine et al., 1984; Harms and Schmincke, 2000). There is a sharp gap between the field observation and the laboratory experiment concerning the behavior of chlorine during syn-eruptive decompression. Recently, Gardner et al. (1998) have shown that at fast decompression rates, $\mathrm{Cl}$ cannot diffuse out efficiently, although water can. On the contrary, when the erupted material cools more slowly $\mathrm{Cl}$ is lost, presumably as a result of groundmass crystallization.

The observed variations in $\mathrm{Cl}$ solubility with pressure for brine-saturated melts may be used to estimate pre-eruptive pressures of the most evolved magmas produced during the Campanian Ignimbrite (CI) eruption (Signorelli et al., 2001), assuming that the system was saturated with both brine and aqueous fluid. As shown in fig. 9, experiments at 25 to $200 \mathrm{MPa}$ using an 


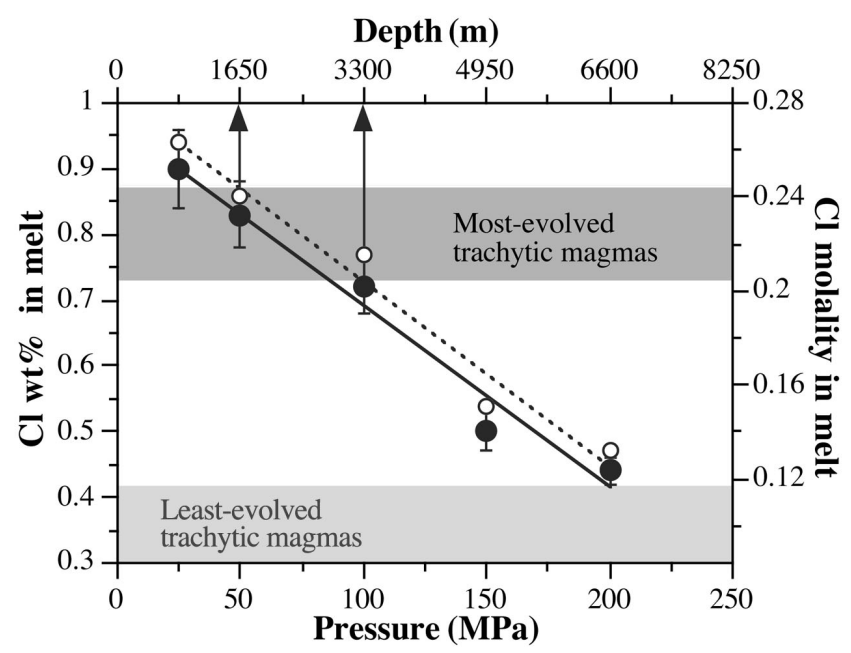

Fig. 9. Chlorine solubility in trachytic melts saturated with aqueous fluid+brine versus pressure (MPa). Solid and open circles represent original and water-free values $( \pm 1 \sigma$ standard deviation), respectively. Shaded areas represent the $\mathrm{Cl}$ distribution in matrix glasses (most-evolved trachytic magma) and glass inclusions (leastevolved trachytic magma). The arrows indicate the inferred depth of the CI magma chamber (from Signorelli et al., 2001).

evolved trachyte from the CI eruption show that the high $\mathrm{Cl}$ contents of these magmas correspond to minimum pre-eruptive pressures of $50-100$ $\mathrm{MPa}$, or depths of only 2-4 km, if the magmas were saturated with both an aqueous fluid phase and a brine prior to eruption, and neglecting possible effects of other components such as $\mathrm{CO}_{2}$ (Signorelli et al., 2001). In fact, the high $\mathrm{Cl}$ contents of these magmas can only be explained if the magmas were brine-saturated prior to eruption. Higher pressures could be possible if the magmas coexisted with only a brine and not an aqueous fluid phase but preliminary data on water fugacities calculated from the compositions of coexisting biotite-magnetite-sanidine present in the CI rocks also suggest water fugacities of 70-130 MPa, consistent with a relatively shallow, vapor-saturated system (Fabbrizio and Carroll, unpubl.).

\section{Conclusions}

Experimental data concerning chlorine solubility in phonolitic to trachytic melts and va- por/melt and hydrosaline brine/melt partitioning of $\mathrm{Cl}$ under magmatic conditions provide insights concerning the geochemical behavior of $\mathrm{Cl}$ in evolved alkaline melts. The results summarized in this study are directly applicable to volcano monitoring by allowing better interpretation of the origins of variations in measured halogen emissions from alkaline magmatic systems. In more general terms, the experimental data on $\mathrm{Cl}$ solubility as a function of magma composition and pressure will provide better constraints on the volcanic degassing of $\mathrm{Cl}$ and help in the identification of eruptive products preserved in the geologic record which may have been associated with large $\mathrm{Cl}$ emissions. This will aid studies seeking to correlate the record of climatic variability with the record of volcanic eruptions and will allow better estimation of past volcanic input to the atmosphere.

At pressures and temperatures outside the vapor-brine immiscibility field of the $\mathrm{NaCl}-\mathrm{H}_{2} \mathrm{O}$ system, the concentration of $\mathrm{Cl}$ in alkaline melts depends on the activity of $\mathrm{Cl}$ in the fluid phase. Under conditions within the vapor-brine immiscibility field, the concentration of $\mathrm{Cl}$ in melt is 
constant and is buffered by the coexistence of aqueous vapor and hydrosaline brine. $\mathrm{Cl}$ partitioning between hydrosaline liquid and melt and $\mathrm{Cl}$ solubility exhibit a strong negative dependence on the pressure, whereas $\mathrm{Cl}$ partitioning between aqueous vapor and melt shows a positive correlation with pressure. These features may be attributed to the shape of the immiscibility field of the $\mathrm{NaCl}-\mathrm{H}_{2} \mathrm{O}$ system. When compared with experimental results on rhyolites, the solubility of $\mathrm{Cl}$ in phonolites and trachytes is approximately twice as high under similar conditions. These results demonstrate that $\mathrm{Cl}$ solubility in hydrous evolved melts is a strong function of melt composition and higher solubilities can be expected in alkali-rich, low silica activity compositions. The strong dependence of $\mathrm{Cl}$ solubility on pressure in magmas saturated with aqueous fluid + brine means that melt $\mathrm{Cl}$ contents might be useful for estimating minimum pre-eruptive pressures, as illustrated for the most evolved (and presumably highest-level) compositions observed in the Campanian Ignimbrite eruption. Additional work is still needed to address the effects of melt composition on $\mathrm{Cl}$ solubility over a range of pressures and temperatures and to quantify the effects of other volatile components (e.g., $\left.\mathrm{F}, \mathrm{CO}_{2}\right)$ on $\mathrm{Cl}$ solubility. The release of $\mathrm{Cl}$ during explosive eruptions may also be influenced by degassing kinetics and this represents another area where more experimental data are needed if we wish to model $\mathrm{Cl}$ release in active volcanic systems.

\section{Acknowledgements}

The work presented in this paper was supported by the Italian GNV-INGV (projects 20002003), funds from the MIUR-FIRB program (2002-2005) and the European Union (contracts ENV-CT97-5081 and ENV4-CT96-0259). Reviews by $\mathrm{M}$. Pichavant and an anonymous reviewer helped to improve the manuscript.

\section{REFERENCES}

Albritton, D.L. (1989): Stratospheric ozone depletion: global processes, in Ozone Depletion, Greenhouse Gases, and Climate Change (National Research Council, Washington, DC), 10-18.
Anderko, A. and K.S. PitZer (1993a): Equation-of-state representation of phase equilibria and volumetric properties of the system $\mathrm{NaCl}-\mathrm{H}_{2} \mathrm{O}$ above $573 \mathrm{~K}$, Geochim. Cosmoschim. Acta, 57, 1657-1680.

Anderko, A. and K.S. Pitzer (1993b): Phase equilibria and volumetric properties of the systems $\mathrm{KCl}-\mathrm{H}_{2} \mathrm{O}$ and Na$\mathrm{Cl}-\mathrm{KCl}-\mathrm{H}_{2} \mathrm{O}$ above $573 \mathrm{~K}$ : equation of state representation, Geochim. Cosmoschim. Acta, 57, 4885-4897.

Bishoff, J.L. (1991) Densities of liquides and vapors in boiling $\mathrm{NaCl}-\mathrm{H}_{2} \mathrm{O}$ solutions: a PVTX summary from 300 to $500^{\circ} \mathrm{C}, \mathrm{Am}$. J. Sci., 291, 309-338.

Bodnar, R.J., C.W. BurnhaM and S.M. STERNER (1985): Synthetic fluid inclusions in natural quartz, III. Determination of phase equilibrium properties in the system $\mathrm{H}_{2} \mathrm{O}-\mathrm{NaCl}$ to $1000^{\circ} \mathrm{C}$ and 1500 bar, Geochim. Cosmochim. Acta, 49, 1861-1873.

CAndela, P.A. and P.M. Piccoli (1995): Model ore-metal partitioning from melts into vapor and vapor/brine mixtures, in Magmas, Fluids and Ore Deposits, edited by J.F.D. ThomPson (Mineral. Assoc. Canada), vol. 23, 101-127.

Carroll, M.R. and J.D. Webster (1994): Solubilities of sulfur, noble gases, nitrogen, chlorine, and fluorine in magmas, in Volatiles in Magmas, edited by M.R. CARROLL and J.R. HollowAY, Rev. Mineral., 30, 231-279.

CHou, I.M. (1987): Phase relation in the system $\mathrm{NaCl}-\mathrm{KCl}-$ $\mathrm{H}_{2} \mathrm{O}$, III. Solubilities of halite in vapor-saturated liquids above $445^{\circ} \mathrm{C}$ and redetermination of phase equilibrium properties in the system $\mathrm{NaCl}-\mathrm{H}_{2} \mathrm{O}$ to $1000^{\circ} \mathrm{C}$ and 1500 bar, Geochim. Cosmochim. Acta, 51, 1965-1975.

Cioni, R., L. Civetta, P. Marianelli, N. Métrich, R. SAnTACROCE and A. SBRANA (1995): Compositional layering and syneruptive mixing of a periodically refilled shallow magma chamber: the A.D. 79 Plinian eruption of Vesuvius, J. Petrol., 36, 739-776.

Cioni, R., P. MARianelli and R. SANTACRoce (1998): Thermal and compositional evolution of the shallow magma chambers of Vesuvius: evidence from pyroxene phenocrysts and melt inclusions, J. Geophys. Res., 103, 18277-18294.

Cornell, W.C. and H. Sigurdsson (1987): Composition zoning in Pompei 79 A.D. pumice deposit; magma mixing and observed trends, Eos, Trans. Am. Geophys. Un., 68, abstr. 434.

Devine, J.D., H. Sigurdsson and A.N. DAVIS (1984): Estimates of sulfur and chlorine yield to the atmosphere from volcanic eruptions and potential climatic effects, J. Geophys. Res., 89, 6309-6325.

Duffell, H.J., C. Oppenheimer, D.M. Pyle, B. Galle, A.J.S. MCGONIGLE and M.R. BurTon (2003): Changes in gas composition prior to a minor explosive eruption at masaya volcano, Nicaragua, J. Volcanol. Geotherm. Res., 126, 327-339.

Edmonds, M., C. OpPenheimer, D.M. Pyle, R.A. Herd and G. ThOMPSON (2003): $\mathrm{SO}_{2}$ emissions from Soufrie're Hills Volcano and their relationship to conduit permeability, hydrothermal interaction and degassing regime, J. Volcanol. Geotherm. Res., 124, 23-43.

Francis, P., M.R. Burton and C. OPPENHEIMER (1998): Remote measurements of volcanic gas compositions by solar occulation spectroscopy, Nature, 396, 567-570.

Frank, M.R., P.A. CANDEla and P.M. Piccoli (2003): Alkali exchange equilibria between a silicate melt and coexist- 
ing magmatic volatile phase: an experimental study at $800^{\circ} \mathrm{C}$ and $100 \mathrm{MPa}$, Geochim. Cosmochim. Acta, 67, 1415-1427.

GARDNer, J.E., M. Rutherford and M. Hort (1998): Degassing of trace gases during volcanic eruptions, Eos, Trans. Am. Geophys. Un., 79, abstr. F936.

GigGENBACH, W.F. (1996): Chemical composition in volcanic gases, in Monitoring and Mitigation of Volcanic Hazard, edited by R. SCARPA and R.I. TILLING (Berlin, Heidelberg, Springer-Verlag), 221-256.

HARMS, E. and H.U. SCHMINCKE (2000): Volatile composition of the phonolitic Laacher See magma (12900 years BP): implications for syneruptive degassing of $\mathrm{S}$, F, Cl and $\mathrm{H}_{2} \mathrm{O}$, Contrib. Mineral. Petrol., 138, 84-98.

HedenQuist, J.W. (1995): The ascent of magmatic fluid: Discharge versus mineralization, in Magmas, Fluids and Ore Deposits, edited by J.F.D. Thompson (Mineral. Assoc. Canada), vol. 23, 263-289.

HeDENQUist, J.W. and J.B. LowENSTERN (1994): The role of magmas in the formation of hydrothermal ore deposits, Nature, 370, 519-527.

Holland, H.D. (1972): Granite, solutions, and base metal deposits, Econ. Geol., 67, 281-301.

IwASAKI, B. and T. KATSURA (1967): The solubility of hydrogen chloride in volcanic rock melts at a total pressure of one atmosphere and at temperatures of $1200^{\circ} \mathrm{C}$ under anhydrous conditions, Bull. Chem. Soc. Jpn., 40, 554-561.

Johnston, D. (1980): Volcanic contribution of chlorine to the stratosphere: More significant to ozone that previously estimated?, Science, 209, 491-492.

KILINC, I.A. and C.W. BuRnham (1972): Partitioning of chloride between a silicate melt and coexisting aqueous phase from 2 to $8 \mathrm{~kb}$, Econ. Geol., 67, 231-235.

Kotlova, A.G., Y.I. Ol'shanskiI and A.I. TsvetKov (1960): Some trends in immiscibility effects in binary silicate and borate systems, Mineral. Geokhim. Tr. Inst. Geol. Rudn. Mest. AN SSSR, 42, 3-9.

KravchuK, I.F. and H. KePPler (1994): Distribution of chloride between aqueous fluids and felsic melts at 2 kbar and $800^{\circ} \mathrm{C}$, Eur. J. Mineral., 6, 913-923.

Love, S.P., F. Goff, D. Counce, C. Siebe and H. Delgado (1998): Passive infrared spectroscopy of the eruption plume at Popocatépetl volcano, Mexico, Nature, 396, 563-567.

LOWEnSTERn, J.B. (1994): Chlorine, fluid immiscibility, and degassing in peralkaline magmas from Pantelleria, Italy, Am. Mineral., 79, 353-369.

LOWENSTERN, J.B. (1995): Applications of silicate melt inclusions to the study of magmatic volatiles, in Magmas, Fluids and Ore Deposits, edited by J.F.D. TномPson (Mineral. Assoc. Canada), vol. 23, 71-99.

Malinin, S.D., I.F. KravchuK and F. Delbove (1989): Chloride distribution between phases in hydrated and dry chloride-alumosilicate melt systems as a function of phase composition, Geochem. Int., 26, 32-38.

MÉtrich, N. and M.J. Rutherford (1992): Experimental study of chlorine behavior in hydrous silicic melts, Geochim. Cosmochim. Acta, 56, 607-616.

Mues-Schumacher, U. (1994): Chemical variations of the 79 A.D. pumice deposits of Vesuvius, Eur. J. Mineral., 6, 387-395.

RoEDDER, E. (1984): Fluid inclusions (Min. Soc. America),
Rev. Mineral., 12, pp. 644.

SHINOHARA, H. (1994): Exsolution of immiscible vapor and liquid phases from a crystallizing silicate melt: Implications for chlorine and metal transport, Geochim. Cosmochim. Acta, 58, 5215-5222.

Shinohara, H., J.T. IIyama and S. Matsuo (1989): Partition of chlorine compounds between silicate melt and hydrothermal solutions, Geochim. Cosmochim. Acta, 53, 2617-2630.

SignORELli, S. and B. CAPACCIONI (1999): Behavior of chlorine prior and during the 79 A.D. Plinian eruption of Vesuvius (Southern Italy) as inferred from the present distribution in glassy mesostases and wholepumices, Lithos, 46, 715-730.

SignORELli, S. and M.R. CARROLL (2000): Solubility and fluid-melt partitioning of $\mathrm{Cl}$ in hydrous phonolitic melts, Geochim. Cosmochim. Acta, 64, 2851-2862.

Signorelli, S. and M.R. CARroll (2001): Chlorine solubility in peraluminous rhyolites from Soufriere Hills volcano, Montserrat: implications for magmatic degassing, Bull. Volcanol., 62, 431-440.

SignORELli, S. and M.R. CARROLl (2002): Experimental study of $\mathrm{Cl}$ solubility in hydrous alkaline melts: constraints on the theoretical maximum amount of $\mathrm{Cl}$ in trachytic and phonolitic magmas, Contrib. Mineral. Petrol., 143, 209-218.

Signorelli, S., G. Vaggelli and C. Romano (1999): Preeruptive volatile $\left(\mathrm{H}_{2} \mathrm{O}, \mathrm{F}, \mathrm{Cl}\right.$ and $\left.\mathrm{S}\right)$ contents of phonolitic magmas feeding the 3550-year-old Avellino eruption from Vesuvius, Southern Italy, J. Volcanol. Geotherm. Res., 93, 237-256.

Signorelli, S., G. Vaggelli, C. Romano and M.R. CARROLL (2001): Volatile zoning $\left(\mathrm{H}_{2} \mathrm{O}, \mathrm{F}, \mathrm{Cl}, \mathrm{S}\right)$ of Campanian ignimbrite magmas (Phlegraean Fields, Italy): evidence from the study of glass inclusions and matrix glasses, Contrib. Mineral. Petrol., 140, 543-553.

SouriRajAN, S. andy G.C. Kenned (1962): The system $\mathrm{H}_{2} \mathrm{O}-\mathrm{NaCl}$ at elevated temperatures and pressures, $\mathrm{Am}$. J. Sci., 260, 115-141.

Student, J.J. and R.J. Bodnar (1999): Synthetic fluid inclusions XIV: coexisting silicate melt and aqueous fluid inclusions in the haplogranite- $\mathrm{H}_{2} \mathrm{O}-\mathrm{NaCl}-\mathrm{KCl}$ system, J. Petrol., 40, 1509-1525.

Symonds, R.B., W.I. Rose and M.H. ReED (1988): Contribution of $\mathrm{Cl}$ - and F-bearing gases to the atmosphere by volcanoes, Nature, 334, 415-418.

WEBSTER, J.D. (1992a): Fluid-melt interactions involving Cl-rich granites: experimental study from 2 to $8 \mathrm{kbar}$, Geochim. Cosmochim. Acta, 56, 659-678.

WEBSTER, J.D. (1992b): Water solubility and chlorine partitioning in Cl-rich granitic systems: effects of melt composition at $2 \mathrm{kbar}$ and $800^{\circ} \mathrm{C}$, Geochim. Cosmochim. Acta, 56, 679-687.

Webster, J.D. (1997a): Exsolution of Cl-bearing fluids from chlorine-enriched mineralizing granitic magmas and implications for ore metal transport, Geochim. Cosmochim. Acta, 61, 1017-1030.

WeBSTER, J.D. (1997b): Chloride solubility in felsic melts and the role of chloride in magmatic degassing, $J$. Petrol., 38, 1793-1807.

Webster, J.D. and B. De Vivo (2002): Experimental and modelled solubilities of chlorine in aluminosilicate melts, consequences of magma evolution, and implica- 
tions for exsolution of hydrous chloride melt at Mt. Somma-Vesuvius, Am. Mineral., 87, 1046-1061.

WeBster, J.D. and J.R. HollowAY (1988): Experimental constraints on the partitioning of $\mathrm{Cl}$ between topaz rhyolite melt and $\mathrm{H}_{2} \mathrm{O}$ and $\mathrm{H}_{2} \mathrm{O}+\mathrm{CO}_{2}$ fluids: New implications for granitic differentiation and ore deposition. Geochim. Cosmochim. Acta, 52, 2091-2105.

Webster, J.D. and C.R. REBbERT (1998): Geochemical evidence of fluid saturation in felsic magma determined through experimental investigation of $\mathrm{H}_{2} \mathrm{O}$ and $\mathrm{Cl}$ solubilities in F-enriched rhyolites melts, Contrib. Mineral. Petrol., 132, 198-207.

Webster, J.D., R.J. Kinzler and E.A. MatheZ (1999): Chloride and water solubiltiy in basalt and andesitic melts and implications for magmatic degassing, Geochim. Cosmochim. Acta, 63, 729-738.

Williams, T.J. (1995): Copper and $\mathrm{HCl}$ in felsic magmatic systems, Ph.D. Thesis (University of Maryland). 